- Правильная подстилка. В качестве подстилки можно использовать овсянку, отруби, или опилки. Ни в коем случае не использовать муку, манку и т.д.

- Правильное питание. Рацион зофобоса состоит из огурцов, яблок и капусты. Огурцами кормить нужно только раз в неделю, одним маленьким кусочком. Если вы будите давать слишком много, тогда в контейнере может появиться плесень или паразиты.

\title{
Заключение
}

В районах Крайнего Севера достаточно сложно содержать экзотических животных-рептилий, если их владелец не научится самостоятельно разводить кормовых насекомых. Кормовых насекомых можно вырастить в домашних условиях, но это достаточно трудоёмкое занятие.

В результате работы сделаны следующие выводы:

1. Для разведения кормовых насекомых нужно использовать большие ёмкости.

2. Для разведения лучше подходят насекомые с большой продолжительностью жизни.

Список литературы:

1. Гиляров М.С. и др. Биологический энциклопедический словарь. М.: Советская энциклопедия, 1986. - 831 с.

2. Кудрявцев С.В. и др. Террариум и его обитатели: Обзор видов и содержание в неволе: Справочное пособие. - М.: Лесн. пром-сть, 1991.

3. Большой мучной хрущак [Электронный ресурс]. - Режим доступа: http://ru.wikipedia.org/wiki/Большой_мучной_хрущак

\section{Биогаз как альтернативное моторное топливо в условиях Севера}

\author{
Кузьмина Р.С., студентка, \\ Северо-Восточный федеральный университет, \\ 2. Якутск \\ E-mail: regiwok95@mail.ru
}

Научный руководитель: старший преподаватель Егорова Е.Н.

В настоящее время на территории Якутии имеется 297 труднодоступных населенных пунктов, где проживают 742500 человек. Всем известно, что в некоторых из этих населенных пунктов отсутствуют автозаправочные станции (АЗС). Это говорит о том, что автовладельцы затрачивают дополнительное расходы для того, чтобы добраться до АЗС.

Сегодня, когда нефтепродукты подорожали, для среднестатистического автовладельца наиболее экономически приемлемым является использование газа в качестве топлива для автомобиля. Также следует учесть, что двигатели внутреннего сгорания (ДВС) своими выбросами загрязняют окружающую среду, но при этом, если двигатель работает на газу, выбросов вдвое, а то и втрое меньше. Путем решения данных проблем послужило бы использование биогазовой технологии утилизации сельскохозяйственных отходов. Внедрение данной технологии позволит решить 
проблему загрязнения окружающей среды, во-первых, отходами животноводства, вовторых, выбросами автотранспорта при использовании в качестве топлива бензина или дизеля.

В данной работе рассмотрена возможность применения биогазовой технологии по переработке навоза крупного рогатого скота в Республике Саха (Якутия) в целом и возможность его применения в Хангаласском районе. По данным Госкомстата РС (Я) от 10.10.2016 количество поголовья домашних животных в Республике составило 455,7 тыс. голов, из которых по Хангаласскому району - 23,6 тыс. голов (табл. 1).

Таблица 1

Структура поголовья скота по категориям хозяйств в РС (Я)

\begin{tabular}{|l|c|c|c|c|c|}
\hline Район & $\begin{array}{c}\text { КРС, } \\
\text { тыс. гол }\end{array}$ & $\begin{array}{c}\text { Лошади, } \\
\text { тыс. гол }\end{array}$ & $\begin{array}{c}\text { Свиньи, } \\
\text { тыс. гол }\end{array}$ & $\begin{array}{c}\text { Птица, } \\
\text { тыс. гол }\end{array}$ & $\begin{array}{c}\text { Итого, } \\
\text { тыс. гол }\end{array}$ \\
\hline По РС (Я) & 233,3 & 170,8 & 27,4 & 87,2 & 455,7 \\
\hline $\begin{array}{l}\text { Хангаласский } \\
\text { район }\end{array}$ & 14,8 & 12,3 & 0,3 & 2,6 & 30 \\
\hline
\end{tabular}

Для того чтобы подсчитать количество газа, которое мы сможем получить путем переработки отходов, мы использовали литературные данные. По результатам многочисленных исследований российских и зарубежных ученых, из 1 кг навоза можно получать в среднем $0,04 \mathrm{~m}^{3}$, из навоза свиньи $0,06 \mathrm{~m}^{3}$, из птичьего помета 0,07 $\mathrm{m}^{3}$ и из конского навоза $0,03 \mathrm{~m}^{3}$ биогаза. Поскольку получаемый биогаз нас интересует в качестве моторного топлива, мы взяли его эквивалентные показатели: из $1 \mathrm{~m}^{3}$ биогаза получают 0,84 л дизельного топлива и 0,74 л бензина.

Нами произведены расчеты по возможному выходу биогаза из отходов животноводства и переведены, согласно эквивалентных показателей, на количество получаемого дизельного топлива или бензина (табл. 2 и 3).

Таблица 2

Количество выхода биогаза из различных видов животных по Хангаласскому району

\begin{tabular}{|c|l|c|c|c|c|c|}
\hline № & $\begin{array}{c}\text { Наименова } \\
\text { ние }\end{array}$ & $\begin{array}{c}\text { Кол-во } \\
\text { голов, } \\
\text { тыс }\end{array}$ & $\begin{array}{c}\text { Выход } \\
\text { отходов, } \\
\text { кг/день }\end{array}$ & $\begin{array}{c}\text { Выход } \\
\text { отходов, } \\
\text { кг/год (тыс) }\end{array}$ & $\begin{array}{c}\text { Выход } \\
\text { биогаза из 1 } \\
\text { кг, } \mathbf{m}^{3}\end{array}$ & $\begin{array}{c}\text { Выход } \\
\text { биогаза, } \\
\text { м }^{3} / \text { год (тыс) }\end{array}$ \\
\hline 1 & КРС & 14,8 & 36 & 194472 & 0,04 & 7778,88 \\
\hline 2 & Свинья & 0,3 & 4 & 1309,5 & 0,06 & 78,57 \\
\hline 3 & Птица & 2,6 & 0,16 & 151,84 & 0,07 & 10,63 \\
\hline 4 & Лошадь & 12,3 & 8 & 35916 & 0,03 & 1077,48 \\
\hline 5 & Итого & & & & & \\
\hline
\end{tabular}

Таблица 3

Выход биогаза и его эквивалентные показатели

\begin{tabular}{|c|c|c|c|c|}
\hline Наименование & $\begin{array}{c}\text { Кол-во голов, } \\
\text { тыс }\end{array}$ & 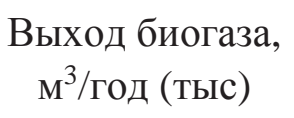 & $\begin{array}{c}\text { Дизтопливо, л } \\
\text { (тыс) }\end{array}$ & $\begin{array}{c}\text { Бензин, л } \\
\text { (тыс) }\end{array}$ \\
\hline КРC & 14,8 & 7778,88 & 6534,3 & 5756,4 \\
\hline Свинья & 0,3 & 78,57 & 66 & 58,1418 \\
\hline
\end{tabular}




\begin{tabular}{|c|c|c|c|c|}
\hline Птица & 2,6 & 10,63 & 8,93 & 7,9 \\
\hline Лошадь & 12,3 & 1077,48 & 905,1 & 797,33 \\
\hline Итого & - & 9997,93 & 7514,33 & 6619,8 \\
\hline
\end{tabular}

Таблица 4

Количество выхода биогаза из различных видов животных по Республике Саха (Якутия)

\begin{tabular}{|l|l|c|c|c|c|c|}
\hline Район & Наименование & $\begin{array}{c}\text { Кол-во } \\
\text { голов }\end{array}$ & $\begin{array}{c}\text { Выход } \\
\text { отходов, } \\
\text { кг/день }\end{array}$ & $\begin{array}{c}\text { Выход } \\
\text { отходов, } \\
\text { кг/год (тыс) }\end{array}$ & $\begin{array}{c}\text { Выход } \\
\text { биогаза из } \\
1 \text { кг, м }\end{array}$ & $\begin{array}{c}\text { Выход } \\
\text { биогаза, } \\
\mathbf{m}^{3} / \text { год (тыс) }\end{array}$ \\
\hline \multirow{2}{*}{$\begin{array}{l}\text { По РС } \\
(Я)\end{array}$} & КРС & 233,3 & 36 & 3065562 & 0,04 & 122622,5 \\
\cline { 2 - 7 } & Свиньи & 27,4 & 4 & 40004 & 0,06 & 2400,24 \\
\cline { 2 - 7 } & Птица & 87,2 & 0,16 & 5092,5 & 0,07 & 356,5 \\
\cline { 2 - 7 } & Лошади & 170,8 & 8 & 498736 & 0,03 & 14962,08 \\
\hline
\end{tabular}

Таблица 5

Выход биогаза и его эквивалентные показатели

\begin{tabular}{|c|c|c|c|c|c|}
\hline Район & Наименование & $\begin{array}{c}\text { Кол-во } \\
\text { голов } \\
\text { (тыс) }\end{array}$ & $\begin{array}{c}\text { Выход } \\
\text { биогаза, } \\
\text { м³/год (тыс) }\end{array}$ & $\begin{array}{c}\text { Дизтопливо, л } \\
\text { (тыс) }\end{array}$ & $\begin{array}{c}\text { Бензин, л } \\
\text { (тыс) }\end{array}$ \\
\hline \multirow{5}{*}{$\begin{array}{l}\text { По РC } \\
\text { (Я) }\end{array}$} & KPC & 233,3 & 122622,5 & 103002,9 & 90740,65 \\
\hline & Свиньи & 27,4 & 2400,24 & 2016,2 & 1776,2 \\
\hline & Птица & 87,2 & 356,5 & 299,5 & 263,81 \\
\hline & Лошади & 170,8 & 14962,08 & 12568,15 & 11071,94 \\
\hline & Итого & - & 140341,32 & 117886,75 & 221739,35 \\
\hline
\end{tabular}

Поскольку наши интересы лежат в области автомобильного транспорта и затрат, связанных с ним, то экономическую часть рассчитаем по количеству получаемого автомобильного топлива из биогаза.

По данным на октябрь 2016 года наличие легковых автомобилей в личной собственности граждан РС (Я) - 210380 единиц, из них в Хангаласском районе - 6411 единиц.

Если рассчитать, что владелец частного легкового автомобиля в день тратит примерно 5 литров бензина, то получим 250 руб. в день. Итого в год 91250 рублей.

Таким образом, по всему району получим: 6411 легковых автомобилей * 91250 рублей = 585003750 рублей в год.

Используя биогазовую технологию, мы сможем сэкономить следующее кол-во литров бензина: 6619800 бензина как эквивалентного показателя биогаза * 50 рублей = 330990000 рубля в год.

Список литературы:

1. Баадер В., Доне Е., Бренндерфер М. Биогаз. Теория и практики. - М.: КОЛОС, 1982. - 140 с. 
2. Мариненко Е.Е. Основы получения и использования биотоплива для решения вопросов энергосбережения и охраны окружающей среды в сельском хозяйстве. Учебное пособие / Волгоград: Изд-во ВолгГАСА, 2003. - 100 с.

3. [Электронный ресурс]. - Режим доступа: www.agrobiogaz.ru

\title{
Продуктивность смородины чёрной и устойчивость к фитопатогенам в условиях Брянской области
}

\section{Лазарев М.С., студент, ФГБОУ ВО «Брянский государственный аграрный университет», с. Кокино, Брянская обл. E-mail: aniri0509@yandex.ru}

\author{
Научный руководитель: \\ д.с.-х.н., доцент Сазонов Ф.Ф.
}

В условиях средней полосы России одним из надежных и эффективных источников увеличения потребления витаминной продукции являются ягодные культуры, возделывание которых имеет существенные преимущества по сравнению с рядом древесных плодовых пород. Малогабаритные ягодные растения отличаются быстрым вступлением в плодоношение, ранним сроком созревания плодов, высокими и регулярными урожаями, надежной адаптацией к условиям выращивания, технологичностью возделывания [1, стр. 89].

Смородина чёрная - популярная ягодная культура, широко возделываемая во многих регионах страны. Она считается одним из лучших видов ягодного сырья, особенно при производстве джема, мармелада, сока и напитков на его основе [10, стр. 29]. Установлено, что потенциальная урожайность лучших современных сортов смородины чёрной достигает 50-60 т/га, а фактическая - не превышает 10 т/га. В производственных условиях урожайность ещё ниже - не более 3-5 т/га [9, стр. 3].

Основным лимитирующим факторам, сдерживающим увеличение производственных посадок смородины чёрной, является низкая адаптация основного культивируемого сортимента к воздействию неблагоприятных факторов внешней среды, что, как следствие, снижает урожайность насаждений [3, стр. 81]. Альтернативой в реализации потенциала культуры является возделывание адаптированных к местным условиям сортов, отличающихся высокой продуктивностью и самоплодностью [2, стр. 4]. Подобные генотипы позволяют избежать воздействия экологических стрессоров, не требуют применения средств защиты растений от болезней и вредителей, что снижает себестоимость возделывания [7, стр. 11].

Существует тесная связь между потенциальной продуктивностью сорта и его способностью противостоять различным дестабилизирующим воздействиям [4, стр. 36]. Болезни и вредители - серьёзный сдерживающий фактор расширения и роста продуктивности насаждений большинства ягодных культур [6, стр. 16]. От воздействия грибковых болезней и вредителей потери в эпифитотийные сезоны достигают 50\% при резком снижении качества продукции. Причём их концентрация на товарных плантациях с возрастом только возрастает [3, стр. 83]. 